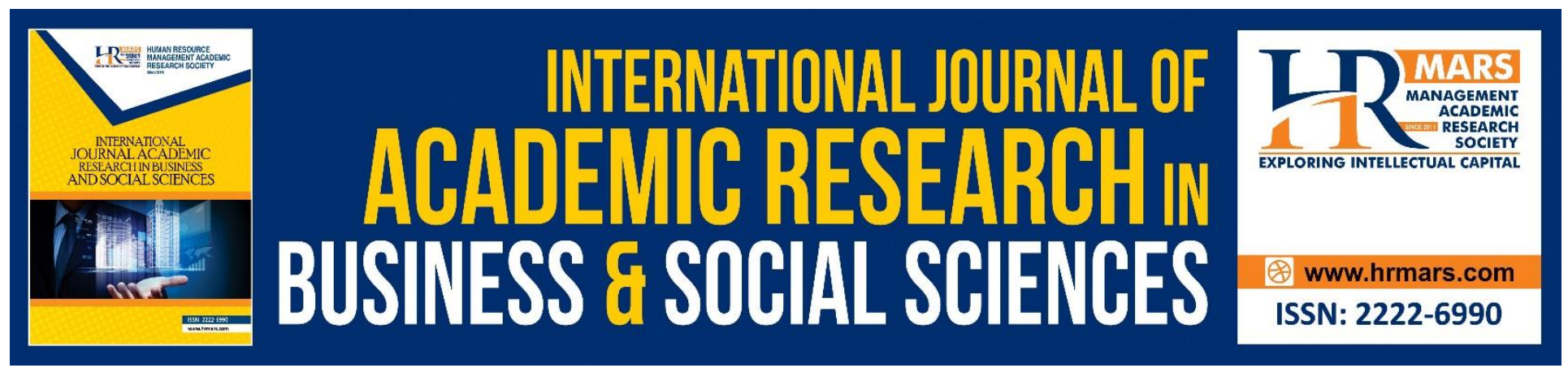

\title{
Buddy System for Students with Disabilities: An Action Research with Embedded Islamic Values and Perspectives
}

\author{
Nor Wahiza Abdul Wahat
}

To Link this Article: http://dx.doi.org/10.6007/IJARBSS/v10-i15/8239

DOI:10.6007/IJARBSS/v10-i15/8239

Received: 20 October 2020, Revised: 30 October 2020, Accepted: 21 November 2020

Published Online: 30 November 2020

In-Text Citation: (Wahat, 2020)

To Cite this Article: Wahat, N. W. A. (2020). Buddy System for Students with Disabilities: An Action Research with Embedded Islamic Values and Perspectives. International Journal of Academic Research in Business and Social Sciences, 10(15), 142-153.

Copyright: (C) 2020 The Author(s)

Published by Human Resource Management Academic Research Society (www.hrmars.com)

This article is published under the Creative Commons Attribution (CC BY 4.0) license. Anyone may reproduce, distribute, translate and create derivative works of this article (for both commercial and non-commercial purposes), subject to full attribution to the original publication and authors. The full terms of this license may be seen at: http://creativecommons.org/licences/by/4.0/legalcode

Special Issue: Youth and Community Wellbeing: Issues, Challenges and Opportunities for Empowerment V1, 2020, Pg. 142 - 153

Full Terms \& Conditions of access and use can be found at http://hrmars.com/index.php/pages/detail/publication-ethics 


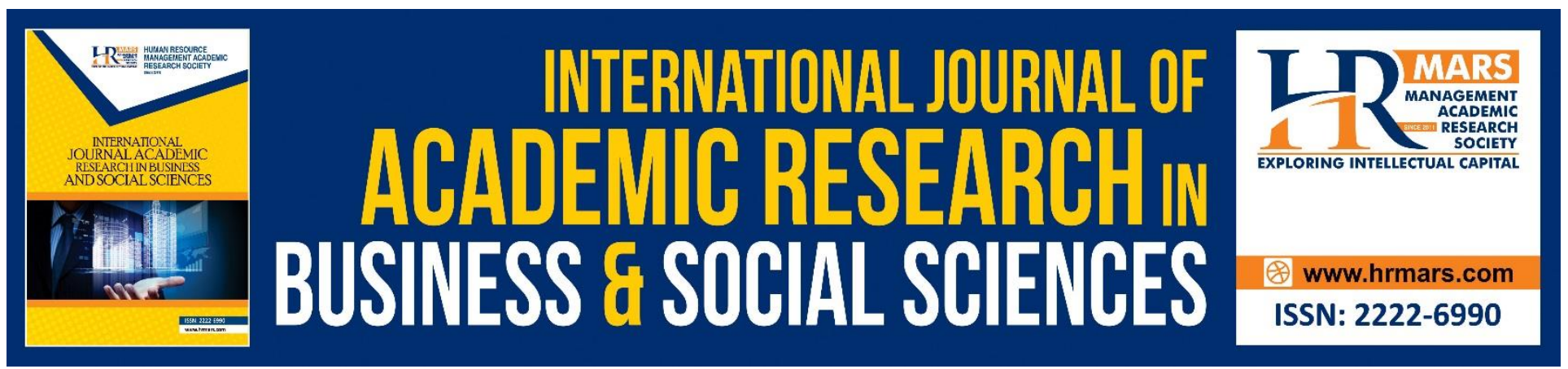

\title{
Buddy System for Students with Disabilities: An Action Research with Embedded Islamic Values and Perspectives
}

\author{
Nor Wahiza Abdul Wahat \\ Institute of Social Science Studies, Universiti Putra Malaysia, 43400, Serdang, Selangor, \\ Malaysia \\ Email:wahiza@upm.edu.my
}

\begin{abstract}
Disabilities are not a negligent issue in Islam. In the Quran, Sunnah, and Islamic history, there have been many provisions of philosophy, values, incidents, and examples in fulfilling the special needs of the disabled. In the citation of Islamic History itself, Prophet Muhammad (P.B.U.H), as a great leader had demonstrated his way of honoring the needs of people with disabilities. This paper focused on an action research project by bachelor degree students in Universiti Putra Malaysia (UPM), namely the Buddy System for Disabled Students. Embedded within the project are Islamic perspectives and values towards disability. The bachelor disabled students in Universiti Putra Malaysia were characterized with various categories of disabilities. The underlying theoretical framework is the integration of the person-environment perspective and sponsorship mobility model. The process leads to the implementation of needs analysis, plans of actions, and performance with continuous review and implementation towards fulfilling the students' needs with disabilities. This action research project's expected outcomes are better quality in campus life for involved students with disabilities and better socialization, which is important in subjective well-being.
\end{abstract}

Keywords: Disabilities, Islam, Action Research, Buddy System, University

\section{Introduction}

One of the main strategies in the Eleventh Malaysia Plan 2016-2020 to change the current status quo is unlocking productivity potential to ensure sustainable and inclusive growth. As a people-centric development plan, it focuses more on people's economy, thus gearing towards providing better and inclusive access to education, healthcare, housing, and reducing income disparity for Malaysians, including Malaysians with disabilities. Inclusivity towards the equitable society becomes the strategic thrust to achieve the national agenda. In short, no group will be marginalized, including all minority groups. The Eleventh Malaysia Plan has specifically mentioned the persons with disabilities (PWDs), 
whereby the Government will enhance their wellbeing by widening their access to education, skills, and entrepreneurship training (Prime Minister Office, 2016).

As encouragement, the Malaysia Education Blueprint 2013-2015 stated the commitment to cater to students' needs with disabilities by allowing more holistic, accessible and inclusive educational system and environment. In other words, the campuses are aspired to allow more mobile and free movement of students with disabilities. And of equal importance, besides the physical environment (transportation, accommodation, and physical facilities), the campuses also provide a supportive emotional and social environment that builds positive identities, develop a sense of belongingness and realize their full potential (New Straits Times, 2019).

Universiti Putra Malaysia has always geared towards the effort of becoming a disabilityfriendly campus. There are about 20 bachelor disabled students in Universiti Putra Malaysia with diversified categories of disabilities such as physical disability, intellectual disability (slow learner), visually as well as hearing disabilities. Among the facilities are parking lots for people with disabilities, ramps at certain faculty buildings, and renovated residential colleges to tailor students with disabilities. Mobility vans are provided to transport disabled students' mobility to their classes.

The academics and non-academic staff of the university are also dedicated. They contributed their expertise towards the empowerment of people with disabilities in Malaysia in many ways. One of the efforts was the 'Buddy System for Students with Disabilities' project by a batch of Human Resource and Development Students from the Faculty of Educational Studies. The objectives were (a) to identify the needs of students with disabilities in Universiti Putra Malaysia; (b) to develop an action plan in addressing the needs of students with disabilities in Universiti Putra Malaysia, and (c) to develop a socialization circle with students with disabilities in Universiti Putra Malaysia.

An Umayyad Caliph inspired the idea of Buddy System for Students with Disabilities. Umar ibn Abdul Aziz has asked rulers of the provinces to identify blind, disabled, or those with chronic diseases who had difficulties in attending congregational prayers. Upon receiving the list of names, the noble caliph ordered that every blind man should be facilitated by personal assistant to look after and guide him or her. Those with special needs were attended by servants to serve and care for them.

\section{Literature Review}

This particular action research project's underlying theoretical framework integrates the personenvironment perspective, social model, and sponsorship mobility model. The integration of the person-environment view and sponsorship mobility model has been previously proposed in an article entitled 'Towards Developing a Theoretical Framework on Career Success of People with Disabilities' (Wahat, 2011). It was written based on people with disabilities in Malaysia.

The integration of the theories rests within the Islamic perspectives and values towards disability. Islam has always been positive about disability. The negligence of the disabled is definitely against Islam. The Quranic Verse An-Nur (24:61) stated that "There is not upon the blind any guilt or upon the lame any guilt or upon the ill any guilt (for remaining behind). And whoever obeys God and His Messenger. He will admit him to gardens beneath which rivers flow, but whoever turns away, He will punish him with a painful punishment". This verse clearly shows that Islam upholds equality and never support discrimination against persons with disability. 


\section{Person-Environment Perspective}

The person-environment perspective emphasizes positive, significant individual and organizational outcomes due to harmonious interactions between the two (Schneider et al.2000). This perspective was first introduced by Parsons (1909). According to this perspective, it is not sufficient to explain an individual's behavior by focusing on either individual's characteristics or situation alone. Rather, a comprehensive understanding would be possible by looking at the interactions between the two parties.

Complementary fit is one of the main dimensions in the person-environment perspective. It occurs when the individual's characteristics complement what is yet to be completed in the environment to ensure satisfaction and satisfactoriness. Under this dimension's, lies two types of fitness: the needs-supplies and person-job fitness. In this particular context, it would be best to focus on needs-supplies fit. The needs-supplies fitness refers to an environmental role in providing financial, physical, psychological, developmental, and other types of sources needed by individuals within their situation or environment.

\section{Sponsorship Mobility Model}

Meanwhile, the sponsorship mobility model emphasizes the role of organizational sponsorship in helping certain individuals to excel in their performance. Access to activities and certain benefits allow individuals to perform better and thus achieve better performance outcomes. The investments could be in various forms of organizational resources. Previous literature proposed that minority groups were less likely to be chosen for such investments to achieve better success because they are regarded as less worthy (Kanter, 1977; Greenhouse, Parasuraman \& Wormly, 1990).

In this particular context, the university resources could help facilitate disabled students' needs in having a comfortable, quality, and pleasant campus life in Universiti Putra Malaysia. The exploration into the history during the beginning of Islam led us to discover how Saidina Umar Al Khattab has provided housing near a mosque for a blind man after his father came to Saidina Umar to inform his son's difficulty to attend to congregational prayers.

\section{The Social Model of Disability}

The social model of disability (Shakespeare, 2006) emphasized that functional social construction and environment could lead to mobility and accessibility. In other words, dysfunctional social structure and environment impede mobility and thus create impairment. This model proposed that persons with disabilities become impaired and oppressed due to non-accommodating stigma, values, norms, culture, perception, and many other social variables within the environment.

All these eventually lead to immobility and accessibility. As the stigmatized persons are inferior due to certain attributes by the stigmatizing party who feels superior and above others, it created lopsided and inharmonious relationships and an unfriendly social environment. Those who feel good about themselves would not be concern about the needs of those upon whom they looked down. It is not easy for the stigmatized persons with disabilities to escape from such pressing environment as power, social influence, and social control of persons with non-disability compose society's mainstream.

Many theorists explained that stereotypes about stigmatized groups keep the exploitation of the group in persistence. Such social structure is usually preserved for a very long time. One way to 
change or modify the stereotyping and stigmatization within society is via cooperation and interdependence among the societal members. Those belonging to the inferior groups would no longer appear to be of much difference due to certain attributes or expertise which they held. The need for them leads to cooperation and interdependence towards shared goals, which eventually change the perceptions and the nature of relationships (Crocker \& Lutsky, 1986).

The key propositions of the Social Model of Disability areas are listed below (Oliver, 2013).

1. First, impairment is not a disability. The former is an individual factor, while the latter is a social and structural factor;

2. Second, impairment is an individual deficit, while disability is distinctively a social creation due to attitudes and structures of society;

3. Third, the cure for impairment is medical treatment. Meanwhile, the cure for disability is the removal of physical, social, mental, emotional, and social barriers, which means social change.

4. Fourth, disability is not at the fault of individuals. Hence, the enhancement of persons with disabilities' esteem, self-confidence, and a positive sense of collective identity is a goal.

5. The main responsibility to construct an oppression-free and discrimination-free environment is placed on the societal members' shoulders.

In Islam, the application of diversity and pluralistic management could be traced back to Medina Treaty involving the Muhajirin and Ansar. (Embong, Musa \& Muslim, 2018). Helping others and strong cooperation is strongly emphasized in Surah Al-Anfal verse 72: "Indeed, people who have faith and change themselves also fight with their assets and souls on the path of Allah S.W.T and the people who provided them homes and assisted them (to the Muhajirin). They were protective of each other"

In addition to that, as reported from Abu Musa r.a, Rasulullah P.B.U.H dictated, "Indeed a mukmin and another is like a structure, mutually strengthening. As he uttered his words, Rasulullah P.B.U.H had crossed his fingers' (Bukhari, No.285). Thus, the notion of inclusive society which calls for the roles of all community members, be it disabled or non-disabled to help each other and fulfilling the needs of each other via any assets have long been demonstrated. They could be exemplified by the Muhajirin and Ansar towards building solidarity and inclusiveness within a community.

In another Islamic history incident, a Quranic revelation (Abasa, verses 1-13) was endowed to the prophet P.B.U.H after he paid less attention to Abdullah Ibn Umm Maktoom, a blind man who was asked him a question. This indicated that Islam does not tolerate any single mistreatment to the disabled. It was later reported that the blind man became the symbol of inclusion when the man of nobility, Prophet P.B.U.H appointed Abdullah Ibn Umm Maktoom as the caller for prayer and the leader of Medina City when the Prophet P.B.U.H went out for travel.

\section{Methodology}

This study is conducted as an action research. Action Research (AR) is a set of self-consciously collaborative and democratic strategies for generating knowledge and designing action in which trained experts in social and other research and local stakeholders work together. The stakeholders' participation is appreciated in this research approach, in the sense that their experiences, thoughts and feelings are very much taken into consideration in the research process and implementation (Greenwood \& Levin, 1998). 
Sagor (2000) defined action research as a disciplined inquiry process conducted by and for those taking action. The primary reason for engaging in action research is to help the actor improve and/or refining his or her action. The ultimate aim of action research is social change. It aims to achieve the social change via three main components, that is (a) action, (b) research, and (c) participation:

(a) action: action refers to the initiatives and efforts to alter or change the community towards a more self-managing state.

(b) research: research refers to the process of generating new, valuable knowledge via systematic theories, models, methodology and analysis.

(c) participation: participation refers to the facilitation of the researchers to the members of the community. It also involves a participatory process whereby everyone in the research project is responsible and accountable to attain the research objectives to a certain degree.

Absence of any of the components means the research can no longer be identified as an action research. In other words, valid social knowledge only derives from practical reasoning and actions. One of the impacts of action research is enhancement of community or organization members in effectively controlling their own destinies. The impact of such capacity should be sustainable. Action research techniques construct the space of learning opportunities to both insiders (who have strong influence in the change process and will live with the created changes in the community) and outsiders of the community (who will later leave the community, such as researchers), in other words all the stakeholders. The learning and changing process however, must be planned. This begins with the definition of research problem forwarded by the community members, which is not necessarily accepted blindly by the researchers, and clarification of the research questions, as an initiation of meaningful social change process. Clarified research questions will then be followed with literature review by research professionals of relevant field.

To facilitate all the above, the communication process should then be in an atmosphere that allow mutual agreed-on problem focus, which features openness, mutual support, and shared communication channels. Smooth and successful communication among all stakeholders is very essential to ensure consistent mutual understanding with each other. Thus, the design of communication arena consisting (a) learning, (b) opening up process and (c) reflection involving all stakeholders is very important

More specifically, Sagor (2000) outlined seven steps in conducting action research. They are as follows:

1. Selecting a focus: This means that the researcher focuses on the aspect or practice which is to be investigated upon;

2. Clarifying theories: This means that the researcher identifies relevant theories in relation to the investigated aspect or practice;

3. Identifying research questions: This means that the researcher develops meaningful research questions to guide the investigation;

4. Collecting data: This means that the researcher starts to collect data to ensure that their actions are valid and reliable. Triangulation of data with various sources and parties (stakeholders) is a must to ensure validity and reliability. 
5. Analysing data: This means that the researcher examines the collected data to understand the phenomenon in order to improve the situation, develop a new state or bring to a new level of social change;

6. Reporting results: The sharing of the action research results and impacts could be through various forms and channels.

7. Taking informed action: This also means action planning and refined practices. This also saves the stakeholders from making past mistakes.

\section{Buddy System for Students with Disabilities as an Action Research Project}

Action research is the most suitable research design for this project. In the past as well as in current studies, action research has been employed largely in disability studies. In action research people with disabilities have the opportunities to learn, thereby developing greater confidence and selfesteem and potentially positively influencing their subsequent employability. Action research may also yield research that is more relevant and accessible to people with disabilities; qualities that may result in more representative findings via improved participation rates. Similarly, action research can benefit the interpretation of findings and the acceptability of subsequent recommendations (Balcazar et al., 2006; McLaughlin, 2010).

In this action research which avoids passive role of subjects, it is very important to involve Disabled Buddies during the design process of the Buddy System for them. It is very much relative to the mantra of "Nothing About Us, Without Us". The action research can affect their lives (Kiernan, 1999). The purpose of action research itself is to ensure social change and the inclusion of those within the research cycles (Conder, Miller \& Mirfin-Veitch, 2011).

Towards the success light, empowering process should be taking place for the students with disabilities to exercise control over their lives, together with the social support. A comprehensive literature review by Stack and McDonald (2014) have reported 21 action research studies involving people with disabilities abroad. The studies were conducted in UK (8), United States (7), Australia (3), Iceland (1), New Zealand (1) and Canada (1). As yet, none has been reported based on Malaysian context.

Nevertheless, prior to the research conduct, the leadership development course students were gently reminded on several challenges which they might encounter, which includes the challenge in engaging themselves with the OKU Buddy, time constraint, procedural and bureaucratic issues, and team members' commitment.

\section{Problem Definition and Needs Analysis of Students with Disabilities in Universiti Putra Malaysia}

There has been an assumption that students with disabilities in Universiti Putra Malaysia would be in need of better assistance and facilitating environment within the varsity to ease their campus life. Nevertheless, such assumption needs to be empirically tested. The first stage, which is problem definition required the students of leadership development course as the researchers to define the accurate, persisting problems and challenges encountered by bachelor programme students with disabilities in Universiti Putra Malaysia.

The procedure is for the students to obtain the name list of the students with disabilities. They then need to choose one disabled Buddy from the list pertained from Student Division Unit (Welfare). 
The students reported efficiency as the university's Student Division Unit was very cooperative and fast in providing them the name list.

The next step was for them to contact, meet and obtain consents from the students with disabilities to be involved as the Disabled Buddy in this project. The Disabled Buddy who agreed to participate have indicated their agreement by signing a consent form.

Upon the approval, the students then progressed to the needs analysis stage by conducting in-depth interviews with their Disabled Buddies to identify the needs and challenges faced by the students with disabilities. Needs analysis is also known as needs assessment. It refers to data collection activities as the basis to develop program or alternative solutions that could fulfil the needs of the studied or targeted group (Iwai et al., 1999; Brindley, 1989). In designing any program, needs analysis is the first step that must be conducted to ensure valid and relevant solution to fulfil required needs of the situation. Since the 1980s, there have been many terms associated with needs analysis (Chambers, 1980) (please refer to Diagram 1). In short, the results of the needs analysis is also the defined problem by the researcher.

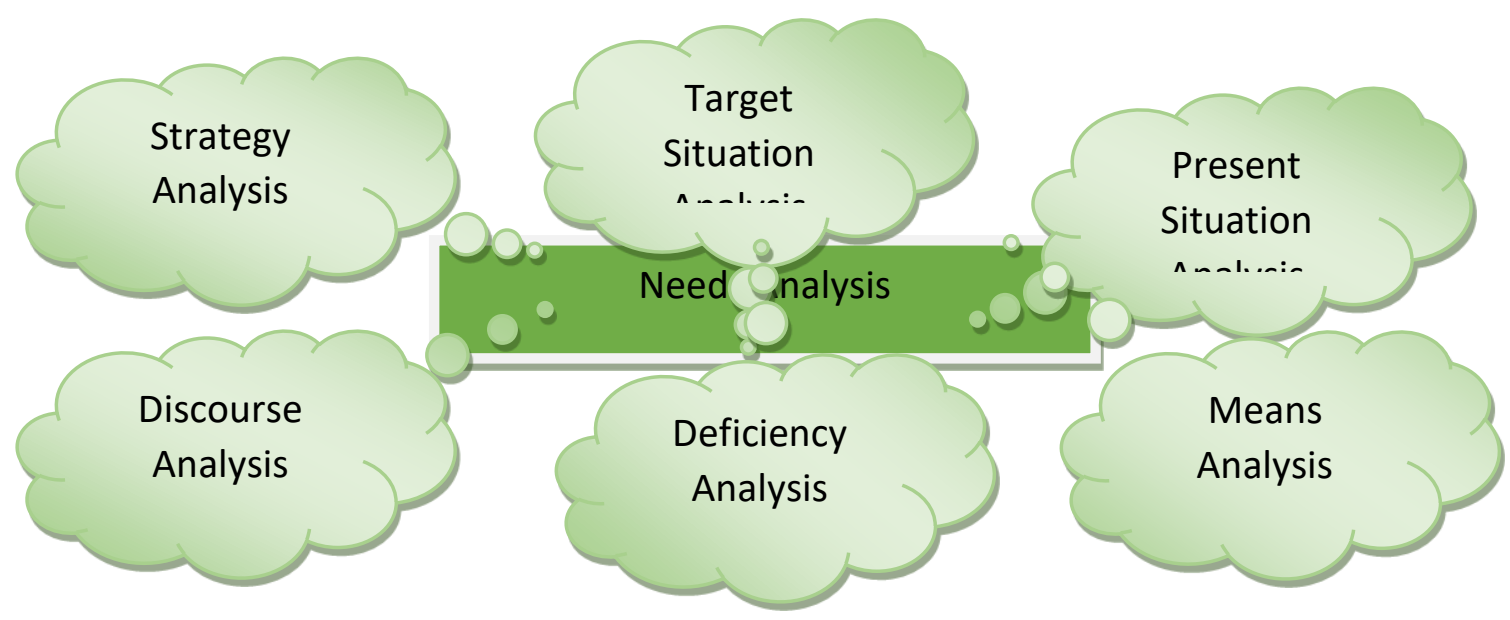

Diagram 1. Terms Associated with Needs Analysis

In this particular study, data on the students with disabilities needs were gathered via indepth interviews. In-depth interviews were the most suitable approach to collect their data because the interview involves social and interpersonal interaction. The results from these in-depths are predicted to result in relevant solutions in addressing the students' needs with disabilities of UPM involved in this project.

The aims of the needs analysis or change to be achieved are measurable outcomes such as improving the quality of campus life, and introducing new ways or encouraging new procedures to ease the students with disabilities' study process.

Data collection is conducted via in-depth interviews. Effective in-depth interviews usually develop and build on intimacy (Johnson, 2002), which could lead to friendship. As such, this data collection actually helped to develop and nurture social relationship between the leadership development students and their Disabled Buddies. Thus, the procedure itself contributed to socialization process between the students and their Disabled Buddies, which is one of the primary 
INTERNATIONAL JOURNAL OF ACADEMIC RESEARCH IN BUSINESS AND SOCIAL SCIENCES

Vol. 10, No. 15, Youth and Community Wellbeing: Issues, Challenges and Opportunities for Empowerment V1. 2020, E-ISSN: 2222-6990 @ 2020 HRMARS

objectives of this project. On the third week of lecture, each group have presented the process of their friendship development with their Disabled Buddies as well as the findings of the needs analysis (defined problem).

The action plans were then developed following the results of the needs analysis of each student with disabilities. In order to design and implement the action plans, the students maintained continuous friendship with their Disabled Buddies. They have also involved their Disabled Buddies in the design process as well. Very often, people or students with disabilities face discrimination, lack of incompetence assumptions and stigmatization due to their body appearance or limited abilities. The impact of one or combination of these would be social exclusion and devaluation of the disabled individuals (Taub et.al., 1999). Thus, building friendships and socialization activities with the Disabled Buddies is very significant. Social support from their surrounding environment such as friends could lead to positive experiences such as development of self-esteem (Roux, 2012).

As discussed earlier in this chapter, the communication process should then be in an atmosphere that allow mutual agreed-on problem focus, which features openness, mutual support, and shared communication channels. Smooth and successful communication among all stakeholders is very essential to ensure consistent mutual understanding with each other. The design of communication arena consisting (a) learning, (b) opening up process and (c) reflection involving all stakeholders. So, this was exactly what had taken place in the designed communication arena of the project.

Triangulation of data took place when the students of leadership development course communicated with stakeholders, such as college management, lecturers as well as university's Department of Student Affairs (Welfare), in the process of ensuring effective, alternative solutions to cater each and different needs of students with disabilities.

\section{Results and Discussion}

The demographic profile and results of needs analysis via in-depth interviews is illustrated in Table 1 below.

Table 1: demographic profile and need anaylsis results

\begin{tabular}{|l|l|l|l|l|}
\hline No & Nick Name and Gender & Programme & Disability and & Needs/Challenges \\
\hline 1 & MF, Male & $\begin{array}{l}\text { Science } \\
\text { Environmental } \\
\text { Technology } \\
\text { Hyperactive } \\
\text { Disorder (ADHD) } \\
\text { and } \\
\text { Aspergers' } \\
\text { Syndrome }\end{array}$ & $\begin{array}{l}\text { Communication and } \\
\text { socialization }\end{array}$ \\
\hline 2 & FL, Male & $\begin{array}{l}\text { Communication } \\
\text { System } \\
\text { Engineering }\end{array}$ & $\begin{array}{l}\text { Physical } \\
\text { (Leg) }\end{array}$ & $\begin{array}{l}\text { Mobility and } \\
\text { movement in non- } \\
\text { accessible premise }\end{array}$ \\
\hline 3 & NA, Female & $\begin{array}{l}\text { Human } \\
\text { Development }\end{array}$ & Physical (Arm) & $\begin{array}{l}\text { Incapability } \\
\text { conduct } \\
\text { tasks and activities }\end{array}$ \\
\hline
\end{tabular}


INTERNATIONAL JOURNAL OF ACADEMIC RESEARCH IN BUSINESS AND SOCIAL SCIENCES

Vol. 10, No. 15, Youth and Community Wellbeing: Issues, Challenges and Opportunities for Empowerment V1. 2020, E-ISSN: 2222-6990 @ 2020 HRMARS

\begin{tabular}{|c|c|c|c|c|}
\hline 4 & NN, Female & Forestry & $\begin{array}{l}\text { Visual } \\
\text { Impairment }\end{array}$ & $\begin{array}{l}\text { Need for books and } \\
\text { article readers; food } \\
\text { delivery and } \\
\text { refrigerator for } \\
\text { medicine storage }\end{array}$ \\
\hline 5 & TK & Consumerism & $\begin{array}{l}\text { Physical } \\
\text { (Arm) }\end{array}$ & $\begin{array}{l}\text { Mobility and } \\
\text { movement in non- } \\
\text { accessible premise }\end{array}$ \\
\hline 6 & SN & $\begin{array}{l}\text { Technology and } \\
\text { Environmental } \\
\text { Science }\end{array}$ & $\begin{array}{l}\text { Physical } \\
\text { (Leg) }\end{array}$ & $\begin{array}{l}\text { Mobility and } \\
\text { movement in non- } \\
\text { accessible premise; } \\
\text { need for food } \\
\text { delivery }\end{array}$ \\
\hline 7 & MR & Malay Language & $\begin{array}{l}\text { Learning } \\
\text { Disability }\end{array}$ & $\begin{array}{l}\text { Need for extended } \\
\text { examination } \\
\text { duration }\end{array}$ \\
\hline 8 & PKW & Computer Science & $\begin{array}{l}\text { Physical } \\
\text { (Leg) }\end{array}$ & $\begin{array}{l}\text { Mobility and } \\
\text { movement in non- } \\
\text { accessible premise }\end{array}$ \\
\hline 9 & MM & Linguistic & Physical & $\begin{array}{l}\text { Mobility and } \\
\text { movement in non- } \\
\text { accessible premise }\end{array}$ \\
\hline
\end{tabular}

Impact refers to a marked effect or influence. The goal of the Buddy System is to build collaboration and relationship between non-disabled students of leadership development course with disabled bachelor degree students of UPM, towards ensuring a convenient campus life for these students with disabilities. Nevertheless, due to some of the challenges which the groups have encountered such as difficulty to engage with the Disabled Buddy, time constraint to meet and socialize with the Disabled Buddy more frequently (some groups have complemented the face to face interaction with WhatsApp group instead), and procedural matters, not all of the sub projects were able to achieve their goals and attain desired impact in terms of benefits for the Disabled Buddies.

As for the case of MR, who was in need of extended examination time, one of the group were able to approach the deputy dean of academic affairs of the relative faculty who had then promised to ensure extended examination duration for all courses throughout MR study years in the completion of his bachelor program. 
As for the case of $\mathrm{NN}$ who is visually impaired, the group has managed to provide her with a sponsored refrigerator to store all her eye medicines. They were also able to arrange food delivery service for her, involving students who stay in the same college. In terms of getting more readers for the assignments, The group has yet to sought for the best solution as there were still limited numbers of readers to assist NN.

As for most of other students with disabilities who were challenged with physical movement and mobility issues, their voices have been heard and reported to the top management of the university. As a world-class university which intends to draw more and more students from diverse demographic characteristics, backgrounds and cultures, the university is ever ready to improve its physical environment to be more inclusive for students with disabilities.

On the other side of the coin, another desired impact is the achievement of the leadership development course objectives itself, which is to provide important concepts, components, processes of leadership development, as well as the opportunities to develop their leadership skills and potentials via challenging experiences. The goal of the whole course is to equip these students with the knowledge, skills and abilities to become credible, humane leaders.

Throughout the cycles of the action research project, the students gradually developed their level of awareness towards the existence of students with disabilities in UPM campus. The disabled students no longer remain invisible despite the fact that they belong to the smallest minority group in the campus. The leadership development course students have actually participated in an action research which involved cycles of (1) identifying the focus, (2) using the research to inform their thinking, (3) identifying specific focus, (4) planning and implementing the intervention, (5) data gathering, (6) data analysing, (7) evaluating and reporting the results, and (8) taking informed action, which refers to solutions by some of the groups towards fulfilling the needs of their Disabled Buddies.

They have also learnt to socialize with and provide social support for the students with disabilities. On the other side of the coin, the disabled buddies have also experienced better socialization and social support with their non-disabled friends in the campus. Socialization is very important to increase their levels of self-esteem as studies have found that students with disabilities have significantly lower level of belief in self and emotional competence compared to non-disabled students, and usually experience less social support (Carnazzo, Dowdy, Furlong \& Quirk, 2018; Cai and Richdale, 2016; Bolourian, Zeedyk \& Blacher, 2018; Chew, Carpenter \& Haase, 2019).

\section{Conclusion}

In conclusion, it is high time to establish the Buddy System for Disabled Students at a larger span and to be part of a disability policy possibly at the university level in order to maintain itself as a world class university. This action would be timely as universities at other part of the globe such as South Africa has also initiated the development of a national policy framework on disability in the postschool education and training systems. It highlights some of the areas where inclusive policies should pay attention in an effort to fully cater for the needs of students with disabilities (Mutanga, 2018).

\section{Acknowledgements}

I would like to extend my heartiest thankfulness to the Department of Student Affairs of Universiti Putra Malaysia for their cooperation in ensuring the success of this study. 


\section{References}

Bolourian, Y., Zeedyk, S. M., \& Blacher, J. (2018). Autism and the university experience: Narratives from students with neurodevelopmental disorders. Journal of autism and developmental disorders, 48(10), 3330-3343.

Boshier, R. (1976). Factor Analysts at Large: A Critical Review of the Motivational Orientation Literature. Adult Education Quarterly, 27 (1): 24-47.

Brookfield, S. (2000). Adult Cognition as a Dimension of Lifelong Learning. City's: The Open University, United Kingdom, London.

Cai, R. Y., \& Richdale, A. L. (2016). Educational experiences and needs of higher education students with autism spectrum disorder. Journal of Autism and Developmental Disorders, 46(1): 31-41.

Carnazzo, K., Dowdy, E., Furlong, M., J., \& Quirk, M., P. (2019). An evaluation of the Social Emotional Health Survey-Secondary for use with students with learning disabilities. Psychology in the Schools, 56(3): 433-446.

Cave, J., LaMaster, C., \& White, S. (2006). Staff Development Adult Characteristics LINC Online. http://ed.fnal.gov/lincon/staff_adult.shtml. Retrieved on $23^{\text {rd }}$ October 2009.

Dewey, J. (1963). Experience and Education., Collier, New York, USA.

Kolb, D., A. (1984). Experiential Learning: Experience as the Source of Learning and Development. Prentice Hall, Englewood Cliffs.

Lieb, S. (1991). Principles of Adult Learning, USA: Arizona Department of Health Services. City Publisher, Arizona, USA.

Wahat, N. W. A. (2011). Towards developing a theoretical framework on career success of people with disabilities. Asian Social Science, 7(3), 62-70.

Schommer, M. (1992). The role of adults' beliefs about knowledge in school, work and everyday life. Smith, M. C., \& Pourchot, T. (1998). Adult Learning and Development. Lawrence Erlbaum Associates, New Jersey, USA.

Senge, P. M. (1990). The Fifth Discipline: The Art and Practice of the Learning Organization. In Linda Lyman, L., Dianne, C., \& Gardner. (2008). Enhancing leadership education: Insights from a seminar evaluation. Journal of Research on Leadership Education, 3(1): 1-34. 